Apidologie, 1982, 13 (3), 265-273.

\title{
COMPARAISON ENTRE L'ÉQUIPEMENT ENZYMATIQUE DES GLANDES SALIVAIRES ET DE L'INTESTIN MOYEN DE DIVERSES ESPÈCES D'ABEILLES SOCIALES
}

\author{
B. DELAGE-DARCHEN*, J. RAMOS de CONCONI et I. CUADRIELlO AGUILAR
}

\begin{abstract}
RÉSUMÉ
Une nouvelle espèce d'abeille sans dard du Mexique. Scaptotrigona mexicana (Guérin) a été étudiée du point de vue de l'équipement en enzymes digestives de ses diverses glandes salivaires et de son intestin moyen.

Les résultats obtenus sont donnés sous forme de tableau synoptique où sont présentés en même temps les résultats déjà acquis avec d'autres espèces d'abeilles sociales.

On peut ainsi constater que la répartition des enzymes recherchées n'est pas identique chez toutes ces espèces qui, pourtant sont toutes consommatrices de nectar, de pollen, et productrices de cire. Les différences métaboliques que l'on note sont sans doute à mettre en rapport avec la qualité du milieu floral qu'elles fréquentent. Cette étude peut donc servir à appréhender la nature des coévolutions qui régissent les rapports plantes-abeilles.

Nous avons déjà étudié à l'aide d'une technique simple (méthode Apizym) l'équipement enzymatique des glandes métamériques annexées au tube digestif antérieur, et de l'intestin moyen d'un certain nombre d'abeilles sociales, trigones, mélipones, Apis (Arnold et Delage-Darchen, 1978; Delage-Darchen et coll., 1979; Delage-Darchen, 1981 sous presse).

A notre grand étonnement, nous nous sommes aperçus que ces abeilles ayant toutes le même régime alimentaire de base, miel et pollen et présentant, par ailleurs, des développements glandulaires comparables, révélaient néanmoins des différences quant à la distribution de diverses enzymes recherchées. Ceci laisse présumer, bien entendu, des métabolismes digestifs quelque peu dissemblables d'une espèce à l'autre.

Continuant cet inventaire, nous avons analysé les enzymes produites par une trigone mexicaine Scaptotrigona.

Plutôt que de décrire simplement nos résultats, nous allons les exposer en un tableau récapitulatif où ils pourront être comparés aux résultats déjà acquis avec $A p o-$ trigona nebulata, trigone centrafricaine, Melipona beecheii, mélipone du Sud du Mexique, et Apis mellifica de France.
\end{abstract}

* Station biologique, 24620 Les Eyzies. 


\section{TECHNIQUE}

Elle est identique en tous points à celle précédemment décrite. Compte tenu de la taille relativement petite de Scaptotrigona, nous avons utilisé pour chaque test, respectivement 35 ou 30 paires de glandes d'ouvrières prises dans le nid. Nous n'avons pas disséqué d'ouvrières très jeunes, reconnaissables à leurs téguments clairs et à leur tube digestif chargé de pollen, car, chez ces individus, les glandes sont encore peu turgescentes et des dissections en nombre sont sujettes à souillures par apport involontaire de tissus étrangers.

Il est difficile de dire si 15 paires de glandes hypopharyngiennes de Melipona sont pondéralement identiques à 30 paires de ces mêmes glandes chez Scaptotrigona, mais néanmoins il est intéressant de constater qu'avec respectivement 15 et 30 paires de ces mêmes glandes chez les deux espèces on obtient tantôt une hydrolyse d'une même intensité (par exemple estérase (C 4) dans les glandes mandibulaires) tantôt des intensités très différentes (par exemple Lipase (C 14)|. C'est ainsi que nous comprenons ces comparaisons, c'est-à-dire en termes relatifs.

\section{RÉSULTATS}

Il est inutile de paraphraser le tableau des résultats. Les petites croix indiquant la plus ou moins forte intensité des réactions de digestion enzymatique, parlent d'ellesmêmes.

Mais on peut dire qu'à part certaines enzymes totalement absentes à un niveau donné chez toutes les espèces, la plus ou moins grande abondance desdites enzymes est généralement très var:able, pour une même glande, chez les 4 espèces étudiées. Et il n'y a pas plus de ressemblances entre les 2 trigones Apotrigona et Scaptotrigona, qu'entre trigones et mélipone. Parfois, même, la distribution des enzymes rapproche plus $S c a p$ totrigona de Melipona, que Scaptotrigona de Apotrigona.

\section{CONCLUSION}

Cet inventaire de routine n'est pas une fin en soi. Dans un premier temps il permet de mettre en évidence des différences dans le fonctionnement de glandes à la fois homologues et morphologiquement très comparables appartenant à diverses abeilles ayant par ailleurs une alimentation du même type.

Ces différences que l'on perçoit, à la faveur de tests aisément reproductibles, permettent alors d'envisager une étude plus approfondie du métabolisme de ces insectes, en relation avec la qualité des nectars et des pollens récoltés. Car, l'éclectisme de ces différentes abeilles n'est qu'apparent. Elles choisissent pour butiner, les fleurs dont la taille, la forme, les cycles biologiques sont aussi les mieux adaptés à leur anatomie et à leur rythme propre, mais aussi celles dont l'odeur ou le goût leur conviennent le mieux.

Ainsi l'étude de la distribution des enzymes digestives chez les abeilles avec ou sans dard, est un biais par lequel on peut aborder le problème de la coévolution des plantes et des insectes pollinisateurs. 


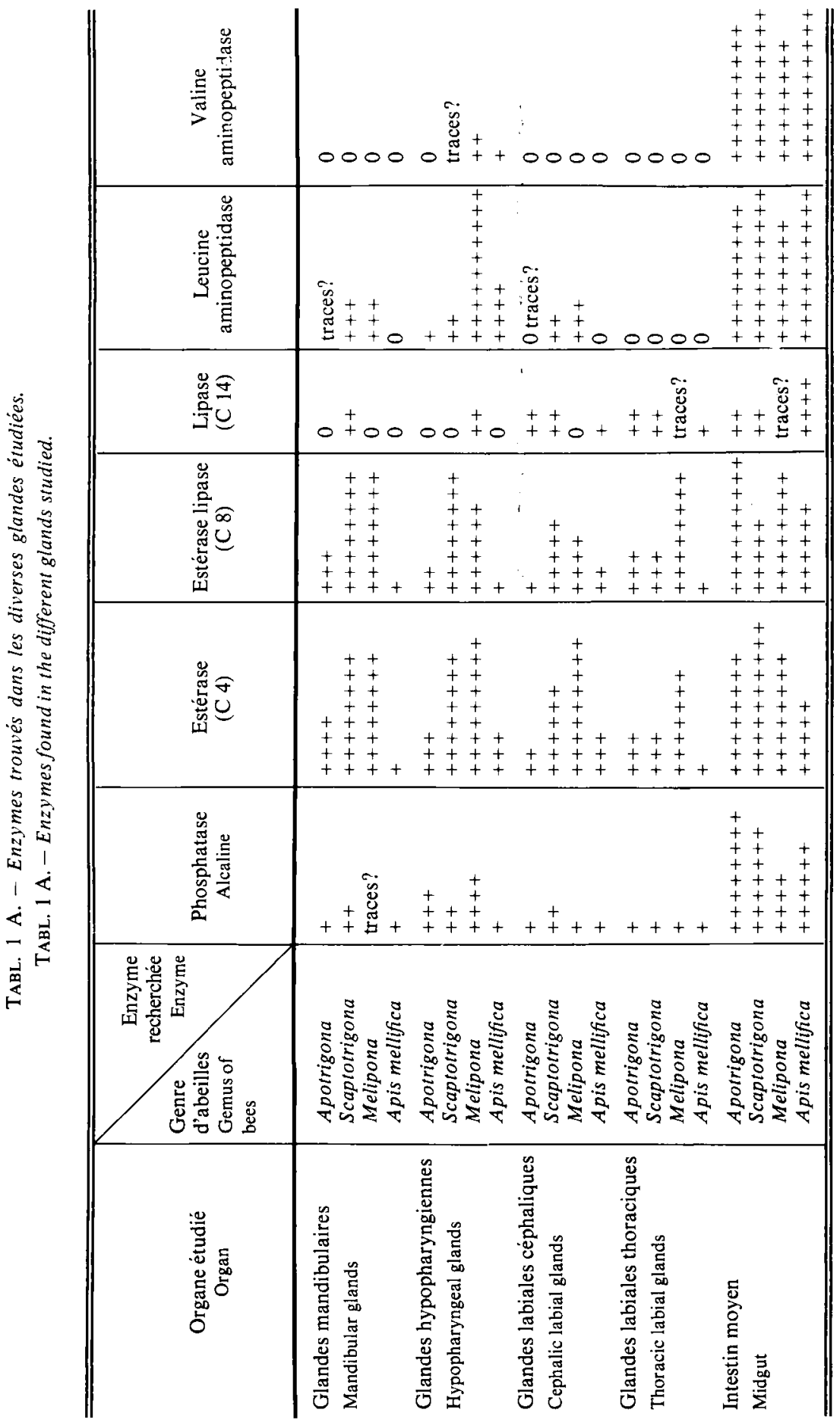




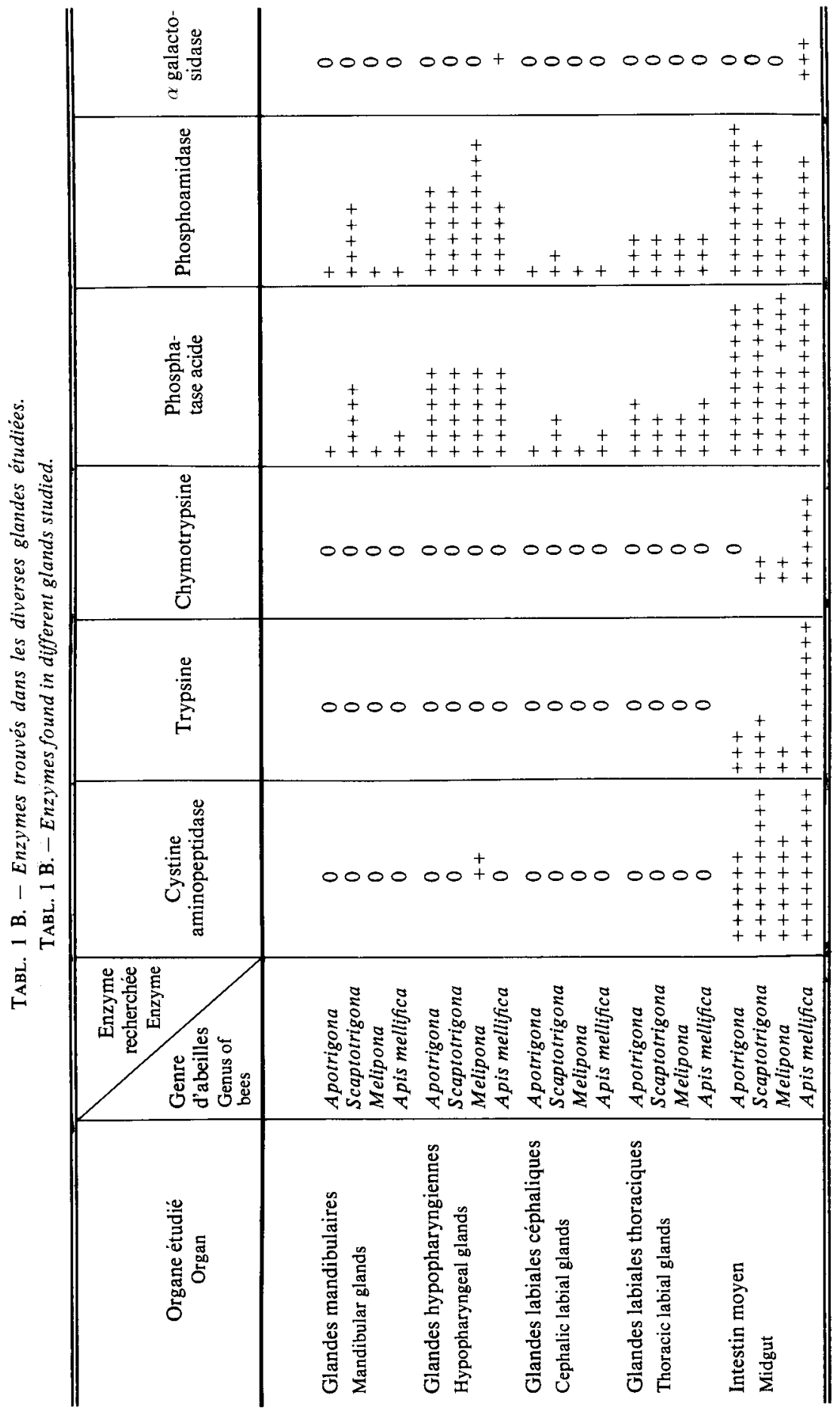




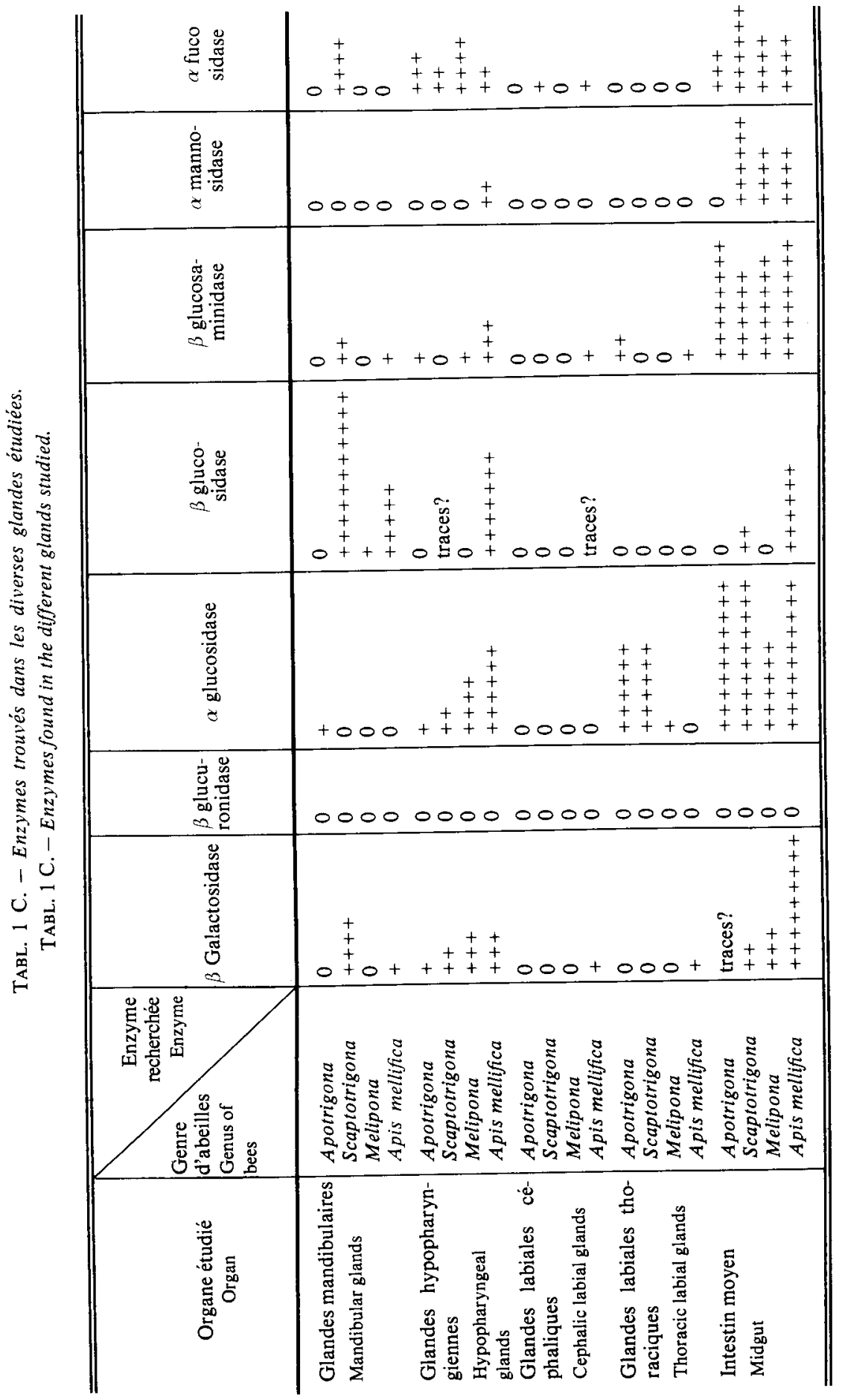


Une récente étude (FEbvay, 1981), à l'aide de la même technique, des enzymes digestives de la fourmi champignoniste sud-américaine Acromyrmex octospinosus a montré que cette fourmi a un équipement enzymatique des plus réduit.

Les abeilles au contraire, en comparaison, sont très richement dotées. Et si, au niveau de leur intestin, des bactéries symbiotes les aident à digérer le pollen, elles assurent quand même par elles-mêmes une grande part de la dégradation et du métabolisme des aliments qu'elles ingèrent et ceci grâce à des sécrétions produites en des sites très divers. Il faut aussi penser que ces sites sécrétoires si diversifiés sont en relation, non seulement avec les processus de digestion proprement dits, mais aussi avec la fabrication du miel. Il est bien évident que ces recherches d'enzymes au niveau des glandes salivaires n'impliquent pas pour autant qu'on suppose qu'elles ne peuvent produire que cela. Chez Apis mellifica, par exemple, les glandes mandibulaires de la reine et de l'ouvrière ont été l'objet d'études dans un tout autre domaine (voir l'ensemble des travaux de PaIN, en particulier). Les glandes mandibulaires des autres espèces d'abeilles que nous avons disséquées produisent des substances très odorantes dont la fonction éthologique est indéniable.

Nous nous sommes penchés ici sur un aspect, seulement, des sécrétions et il reste encore beaucoup à découvrir. Une portion de glande en particulier conserve intacte, ou presque, son énigme, chez toutes les abeilles étudiées, il s'agit de la glande labiale céphalique dont la sécrétion huileuse, incolore contient fort peu d'enzymes et qui ne devient turgescente que chez les abeilles âgées. Jusqu'ici on n'a pu marquer les sécrétions qu'elle contient. Serviraient-elles au travail de la cire? Mais, au moment où la glande s'emplit, l'abeille n'est plus, en théorie, occupée aux constructions.

Malgré l'abondance des travaux dont a été l'objet $A$ pis mellifica, on est donc loin d'avoir tout vu, et peut-être que la comparaison avec des abeilles sans dard amènera à soulever certains voiles de la physiologie de l'abeille domestique, comparaisons intéressantes à faire entre des animaux à mode de vie vraiment très proches, mais, la distribution des enzymes nous le montre, non totalement superposables.

Reçu pour publication en février 1982. Eingegangen im Februar 1982.

\section{ZUSAMMENFASSUNG}

VERGLEICHENDE UNTERSUCHUNGEN DER ENZYMAUSSTATTUNG DER SPEICHELDRÜSEN UND DES MITTELDARMES VON VERSCHIEDENEN ARTEN SOZIALER BIENEN

\section{MATERIAL UND METHODE}

Mit einer leicht anwendbaren und gut standardisierten Nachweismethode wurde bei verschiedenen sozialen Bienenarten die Enzymausstattung der Anhangsdrüsen des vorderen Verdauungstraktes und des Mitteldarmes untersucht. 
Technik. - Die zu bestimmenden Enzyme wurden in kleinen Schälchen von 0,2 ml Inhalt mit spezifischen Testsubstanzen unter Zugabe eines geeigneten Puffers zur Reaktion gebracht. Die Testsubstanzen wurden auf einen kleinen Faserbausch aufgetropft, dann wurde ein wässriges Homogenisat der Drüsen oder eines anderen Gewebes zugegeben. Nach vier Stunden Inkubation bei $37^{\circ} \mathrm{C}$ wird durch geeignete Farbindikatoren die eingetretene Reaktion sichtbar gemacht und nach der Farbintensität klassifiziert.

Jede Serie umfasste in 20 Schälchen 19 Substrate zum Nachweis der wichtigsten Enzyme im Verdauungstrakt der Insekten, sowie eine Leerprobe als Kontrolle.

Untersuchte Gewebe. - Bei allen von uns studierten Arten sozialer Insekten haben wir bei Arbeiterinnen die drei paarigen Anhangsdrüsen des vorderen Verdauungstraktes untersucht: Die Mandibeldrüsen, die Hypopharyngealdrüsen und die Labialdrüsen; letztere treten in zwei Teilen auf - dem Kopfteil und dem Thoraxteil der Labialdrüsen. Diese beiden Abschnitte wurden getrennt untersucht, denn ihre sehr verschiedene Morphologie legt unterschiedliche Funktionen nahe. Ausserdem wurden die Verdauungsenzyme des Mitteldarmes untersucht, da die Verdauung hauptsächlich dort stattfindet.

Untersuchte Bienenarten. - Zuerst wurden die Enzyme von Apis mellifera untersucht, denn erstaunlicherweise gab es für sie bisher keine umfassende, vergleichende Studie der Enzyme. Anschliessend wurden die Verdauungsenzyme von einigen stachellosen Bienen untersucht, und zwar von Apotrigona nebulata aus Afrika und von Melipona beecheii und Scaptotrigona mexicana, beide aus Mexiko; die Daten der letzteren werden hier zum ersten Mal veröffentlicht.

Die Resultate sind aus den Tabellen ersichtlich.

\section{RESULTATE}

Wie man sieht, wurden bei den verschiedenen Arten ganz unterschiedliche Ergebnisse erzielt, obwohl die Untersuchungen von denselben Autoren mit denselben Methoden durchgeführt wurden, und obwohl die Tiere alle dieselbe Ernährungsweise haben (Honig und Pollen) und obwohl die Drüsensysteme nach Aufbau und Entwicklung vergleichbar sind. Man muss daraus schliessen, dass die Rolle der Drüsen bei den einzelnen Arten nicht dieselbe ist, etwa bei der Zubereitung des Honigs. Man muss sich auch die Frage stellen, ob nicht die Unterschiede der enzymatischen Ausstattung nach Quantität und Qualität Ausdruck der Präferenz und der Anpassung an die Verwendung ganz spezifischer Kohlehydrate und Pollen ist.

Diese Untersuchung zielt auf eine künftige Analyse der Koevolution dieser Insekten und der Pflanzen, die ihre Nahrungsgrundlage bilden.

\section{SUMMARY}

THE ENZYMATIC EQUIPMENTS OF THE VARIOUS SALIVARY AND MIDGUT GLANDS OF APIS MELLIFICA WORKERS AND SOME AFRICAN AND AMERICAN WORKER STINGLESS BEES

With the help of an easy and well standardized detection technique we have compared the enzymatic glandular system annexed to the upper digestive tract and those of the midgut of various species of social bees. 
The method used consists of testing reactions between the different enzymes on various substrates placed in small cupels moulded side by side on a plastic tray, with a capacity of approximately $0.20 \mathrm{~cm}^{3}$. The bottom of each of these cupels was lined with a material of unwoven fibres which was impregnated with a special substrate and an adequate buffer. Each cupel was filled with an aqueous suspension of macerated glands, or other tissues to be studied. After four hours of incubation at $37^{\circ} \mathrm{C}$, the reactions obtained were identified using the appropriate reagents. Colours are thus obtained whose intensity varies in relation to the level of hydrolysis of the substrate. A scale of colours using standards were prepared at the same time as the preparation of the substrate, for comparisons of each reaction.

The cupels were distributed by the responsible laboratory in sets of 20 placed on a tray. Nineteen with substrates (and one a blank control). These represented the main enzymatic families encountered in the digestive tract of these insects.

In all species of social bees studied to date, we have taken away the three pairs of metameric glands annexed to the upper digestive tract without prejudging their other possible functions. The analysed glands were : the mandibular glands, the hypopharyngeal and the labial glands which were divided into two parts-labial cephalic and labial thoracic glands. These two parts have been treated independently as their very differing morphology suggests distinct functions. Finally, we also studied the digestive enzymes of the midgut, as it is in this part of digestive tract, that the main digestive processes take place. In this study, only the workers were taken into account.

We have analysed, in various articles, the enzymes produced by several species of bees. Apis mellifica was the first to be chosen, because paradoxically, we had no exhaustive and comparative study of the enzymes of the various glands.

Later, we looked at the digestive enzymes produced by the stingless social bees. We have already described the situation in the case of an African Trigona: Apotrigona nebulata and a Mexican Melipona: Melipona beecheii. Hereunder we bring new results concerning another American Trigona, Scaptotrigona mexicana.

\section{RESULTS}

The different species of bees, studied by the same authors utilising the same technique, gave differing results according to the species. However, the insects used in the experiments all had the same diet honey and pollen - and their glands had comparable morphologies and developments. It may thus be thought that from one species to another, the respective role of these glands may vary (for instance with regard to honey preparation). It is also possible that these differences in the quantity and quality of enzymes produced, reflect a subtle adaptation, permitting the preferential use of various carbohydrates or pollens.

This study suggests a prospect for mutual analysis of the evolution of these insects and the plants ensuring their diet.

\section{BIBLIOGRAPHIE}

ARnold G., Delage-Darchen B., 1978. - Nouvelles données sur l'équipement enzymatique des glandes salivaires de l'ouvrière d'A pis mellifica (Hyménoptère Apide). Ann. Sc. Nat. Zool., 12éré, 20, 401422. 
CRUz LandiM C. da, 1967. - Estudo comparativo de algunas glandulas das abelhas (Hymenoptera, Apoidea) e respectivas implicaçoes evolutivas. Arc. Zool. S. Paulo, 15, 177-290.

Delage-Darchen B., Talec S., Darchen R., 1979. - Sécrétion enzymatique des glandes salivaires et de l'intestin moyen d'une abeille sans dard Apotrigona nebulata (Sm.), (Hyménoptères, Apidés). Ann. Sc. Nat. Zool., 13e série, 1, 261-267.

Delage-Darchen B., Darchen R., 1981. - Les enzymes des glandes digestives et de l'intestin moyen d'une abeille sociale du Mexique, Melipona beecheii (B) (sous presse).

Ö́ösi-Pal Z., in Chauvin R. (Masson 1968). - Traité de biologie de l'abeille, p. 263-290.

Febvay G., 1981. - Quelques aspects (anatomie et enzymologie) des relations nutritionnelles entre la fourmi Attine Acromyrmex octospinosus et son champignon symbiotique. Thèse d'ing ínieur Docteur $n^{\circ}$ IDI 28115.

Pour une bibliographie plus détaillée sur le sujet, consulter celle contenue ả la fin des articles cités en référence. 